\title{
Application of natural oscillation values and limit cycles in the analyses of rail vehicles properties
}

\section{Wykorzystanie wartości drgań własnych i cykli granicznych w analizach właściwości pojazdów szynowych}

\begin{abstract}
The article discusses the application of natural oscillation values and limit cycles in the analyses of the properties of rail vehicles on the basis of experiences of the authors. It is presented the exemplary values of natural oscillation obtained with the use of postprocessors: the amplitude-phase graphs, the root lines and stability cards which make the carrying out of analysis performed by the authors easier. It is also shown the application of limit cycles as a function of vehicle speed to determine the riding stability.
\end{abstract}

Artykut omawia wykorzystanie wartości drgań własnych i cykli granicznych $w$ analizach wtaściwości pojazdów szynowych na podstawie doświadczeń autorów. Przedstawiono przyktadowe wartości drgań własnych uzyskane $z$ wykorzystaniem postprocesorów: wykresów amplitudowo-fazowych, linii pierwiastkowych $i$ kart stabilności, ułatwiajacych przeprowadzenie analiz wykonanych przez autorów. Przedstawiono także wykorzystanie cykli granicznych $w$ funkcji prędkości jazdy pojazdu w celu określenia stabilności jazdy.

\section{INTRODUCTION}

Methods of computer simulations are becoming more and more important in the design process and testing of various mechanical objects. One of the issues, that is intensively developed with these methods, is a mechanics of rail vehicles movement on the railway track. Development and realization of a growing number of computer programs operating in this range and achievement of compliance of their results with the results of experimental tests allow to successively replace the expensive experimental methods with them.

The most important currently used in the world programs in the railway industry include:
- MEDYNA
- SIMPACK
- VAMPIRE
- VI Rail (Adams Rail)
- NUCARS
- Universal Mechanism
- MODKAT

With their help it can be simulated a lot of mechanical phenomena, made the analyses of the results and they can be presented in a condensed graphical form. In this article it is limited only to discussion of the analysis of the natural oscillation values of rail vehicles and additionally the limit cycles. They include the simulations after a time of linear and any

\section{WSTĘP}

Metody symulacji komputerowych mają coraz większe znaczenie $\mathrm{w}$ procesie projektowania $\mathrm{i}$ badania różnorodnych obiektów mechanicznych. Jednym z zagadnień, które tymi metodami jest intensywnie rozwijane to mechanika ruchu pojazdów szynowych po torze kolejowym. Rozwój i realizacja coraz większej ilości programów komputerowych działających w tym zakresie i uzyskanie zgodności ich wyników z wynikami badań doświadczalnych pozwalają na sukcesywne zastępowanie nimi drogich metod doświadczalnych.

Do najważniejszych stosowanych obecnie na świecie programów w branży kolejowej należą:
- MEDYNA
- SIMPACK
- VAMPIRE
- VI Rail (Adams Rail)
- NUCARS
- Universal Mechanism
- MODKAT

$\mathrm{Z}$ ich pomocą można symulować wiele zjawisk mechanicznych, dokonywać analiz wyników i przedstawiać je w skondensowanej postaci graficznej. W niniejszym artykule ograniczono się jedynie do omówienia analizy wartości drgań własnych pojazdów szynowych i dodatkowo cykli granicznych. Obejmuja one symulacje po czasie modeli liniowych i dowolnie 
nonlinear models with the functions changeable with using the active control of the movement of their subassemblies. However, more often it is carried out the analysis of natural oscillation of linearized models by matrix methods, accepting the loss of some original features of nonlinear models and the loss of results accuracy.

At the design stage of the vehicle the methods of natural oscillation analysis are mainly used for determining the frequency and decrements in the assessment of the stability of motion and the possible harmful mutual coupling of these oscillation.

The stability of the rail vehicle is mainly connected with the certain characteristics of wheelsets, such as the conicity of the wheel running profile, the angle of inclination of the tread relative to the surface of the track, the ellipses size of the wheels contact with the rail heads, as well as with its mass and moments of inertia. The free railway wheelset has the unstable stability and the wheelsets carried in the vehicle are stabilized by their constrainment. Only at higher speeds the properties of this carrying significantly affect the dynamic phenomena and including the variation of friction coefficients of the wheels on the rails causing the occurrence of the phenomenon of oscillation amplitudes increasing of wheelsets (instability).

Two types of vehicle movement instability can be:

- directional stability - occurring at the medium speeds and small conicity of wheel-rail

- hunting of rail vehicle - occurring for bigger conicity and higher speeds, considered as more dangerous and ended with limit cycle.

Determination of directional instability is realized by matrix numerical methods including the process of determining the natural oscillation values and vectors of own models subjected to the process of linearization of equations of motion. The results of this analysis are represented by the extensive and not much communicative numerical files. For their presentation in a condensed graphic form the specific digital processing must be made and they must be presented one by one in the form of:

- a set of amplitude-phase graphs of the individual form of oscillation,

- lines graphs of the natural oscillation frequencies (determined with the help of many files of natural oscillation values)

- stability cards (determined with the help of many line graphs of files of natural oscillation values).

In the analysis of natural oscillation of nonlinear models the most often it is interested in the oscillation of small amplitudes. If these models do not have the hysteresis, the simplification by linearization does not cause the significant differences of results. For example, the linearization causes the replacement of non- nieliniowych $\mathrm{z}$ funkcjami przełączalnymi z zastosowaniem aktywnego sterowania ruchem ich podzespołów. Częściej jednak wykonuje się analizy drgań własnych modeli zlinearyzowanych metodami macierzowymi, godząc się z utratą niektórych pierwotnych cech modeli nieliniowych i utratą dokładności wyników.

$\mathrm{Na}$ etapie projektowania pojazdu metody analizy drgań własnych wykorzystywane są głównie w określaniu częstotliwości i dekrementów w ocenie jego stabilności ruchu i ewentualnego szkodliwego wzajemnego sprzęgania się tych drgań.

Stabilność pojazdu szynowego związana jest głównie z pewnymi cechami zestawów kołowych, takimi jak stożkowatość profilu jezdnego koła, kąt nachylenia powierzchni tocznej koła względem płaszczyzny toru, wielkość elips styku kół z główkami szyn a także z jego masą i momentami bezwładności. Swobodny kolejowy zestaw kołowy posiada stabilność chwiejną a zestawy kołowe prowadzone w pojeździe są stabilizowane przez ich skrępowanie. Dopiero przy większych prędkościach jazdy właściwości tego prowadzenia wpływają znacząco na zjawiska dynamiczne a w tym na zmienność współczynników tarcia kół po szynach, co powoduje pojawienie się zjawiska narastania amplitud drgań zestawów kołowych (niestabilności).

Można wyróżnić dwa typu niestabilności ruchu pojazdu:

- stabilność kierunkową - występującą przy umiarkowanych prędkościach jazdy i małej stożkowatości koło-szyna

- wężykowanie pojazdu szynowego - występujące dla większych stożkowatości i większych prędkościach jazdy, uważane za bardziej niebezpieczne i kończące się cyklem granicznym.

Określanie niestabilności kierunkowych realizowane jest macierzowymi metodami numerycznymi obejmującymi proces określania wartości drgań własnych i wektorów własnych modeli poddanych procesowi linearyzacji równań ruchu. Wyniki tej analizy są reprezentowane przez obszerne i mało komunikatywne pliki liczbowe. Dla ich prezentacji w skondensowanej formie graficznej trzeba wykonać specyficzną obróbkę cyfrową i przedstawić je kolejno w postaci:

- zbioru wykresów amplitudowo-fazowych poszczególnych postaci drgań,

- wykresów linii częstotliwości drgań własnych (określonych z pomocą wielu plików wartości drgań własnych),

- kart stabilności (określonych z pomocą wielu wykresów linii wartości drgań własnych).

W analizie drgań własnych modeli nieliniowych najczęściej interesuje się drganiami o małych amplitudach. Jeśli modele takie nie posiadają histerezy to uproszczenie przez linearyzację nie wywołuje znaczą- 
linear damper with the linear damper (Fig. 1), which in spite of appearances gives small differences of results even on the stability limit. This is connected, among other things, with the existence of serial susceptibility of dampers, and oscillation amplitudes just before the limit of unstable motion are small. However, the bigger differences could occur with using in the wagon construction the friction dampers without serial susceptibility, but for constructional reasons it is not often used.

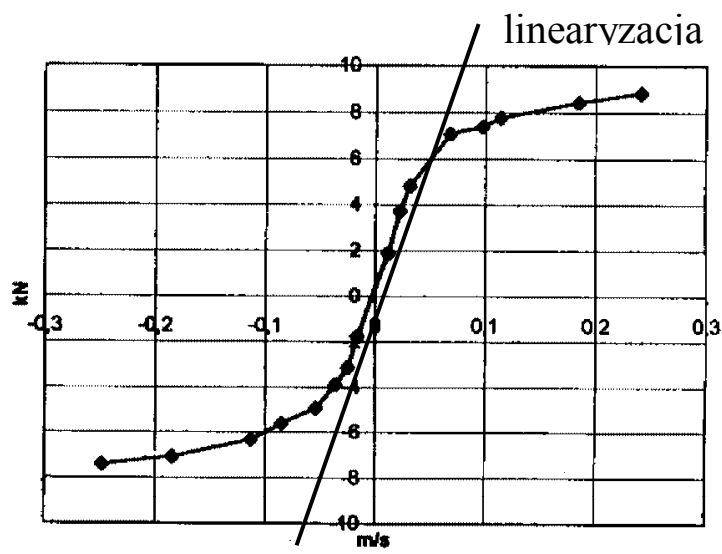

Fig. 1. Linearization of the characteristics of hunting damper Rys. 1. Linearyzacja charakterystyki tłumika wężykowania

While the hunting of wheelsets of the vehicle is determined with the help of numerical integration of the equations of motion describing any non-linear model defined openly or numerically. Interpretation of the results of such simulations is possible in the form so-called. "stability cards", but it is tedious.

\section{THEORETICAL BASICS}

Mathematical model of the linearized system of rail vehicle dynamics normally occurs in the form of :

$$
M \ddot{q}(t)+D \dot{q}(t)+S q(t)=F(t)
$$

where $\mathrm{M}, \mathrm{D}, \mathrm{S}$ are the matrices containing the constants (mass-inertia, damping, elasticity), $\mathrm{q}$ is a vector of generalized coordinates, and $F(t)$ is a vector of enforcing. Considering the free movement of stationary dynamical system, that is, assuming that the vector $F$ is a zero vector, we get the following equation of state after the next transformations in the form of:

$$
\begin{gathered}
M \ddot{q}(t)+D \dot{q}(t)+S q(t)=0 \\
\ddot{q}(t)+M^{-1} D \dot{q}(t)+M^{-1} S q(t)=0 \\
\left\{\begin{array}{l}
\ddot{q} \\
\dot{q}
\end{array}\right\}=\left|\begin{array}{cc}
-M^{-1} D & -M^{-1} S \\
I & 0
\end{array}\right|\left\{\begin{array}{l}
\dot{q} \\
q
\end{array}\right\} \\
\dot{r} \quad A \quad r
\end{gathered}
$$

where $\mathbf{r}$ is the state vector in the form of: $r=\left\{\begin{array}{l}\dot{q} \\ q\end{array}\right\}$ cych różnic wyników. Przykładowo, linearyzacja powoduje zastapienie thumika nieliniowego tłumikiem liniowym (rys. 1), co wbrew pozorom daje nieznaczne różnice wyników nawet na granicy stabilności. Jest to związane między innymi $\mathrm{z}$ istnieniem podatności szeregowej thumików, a amplitudy drgań tuż przed granicą ruchu niestabilnego są małe. Natomiast większe różnice mogłyby się pojawić przy zastosowaniu w konstrukcji wagonu thumików ciernych bez podatności szeregowej, ale ze względów konstrukcyjnych nie stosuje się tego często.

Natomiast wężykowanie zestawów kołowych pojazdu określane jest z pomocą numerycznego całkowania równań ruchu opisujących model dowolnie nieliniowy definiowany jawnie lub numerycznie. Interpretacja wyników takich symulacji jest możliwa w postaci tzw. „kart stabilności” lecz jest żmudna.

\section{PODSTAWY TEORETYCZNE}

Model matematyczny zlinearyzowanego układu dynamiki pojazdu szynowego przyjmuje normalnie postać:

$$
M \ddot{q}(t)+D \dot{q}(t)+S q(t)=F(t)
$$

gdzie $\mathrm{M}, \mathrm{D}, \mathrm{S}$ są macierzami zawierającymi stałe (masowo-bezwładnościowe, thumienia, sprężystości), q jest wektorem współrzędnych uogólnionych, a $\mathrm{F}(\mathrm{t})$ jest wektorem wymuszeń. Rozważając ruch swobodny stacjonarnego układu dynamicznego, czyli przy założeniu, że wektor F jest wektorem zerowym, otrzymamy po kolejnych przekształceniach równania stanu w postaci:

$$
\begin{aligned}
& M \ddot{q}(t)+D \dot{q}(t)+S q(t)=0 \\
& \ddot{q}(t)+M^{-1} D \dot{q}(t)+M^{-1} S q(t)=0 \\
& \left\{\begin{array}{l}
\ddot{q} \\
\dot{q}
\end{array}\right\}=\left|\begin{array}{cc}
-M^{-1} D & -M^{-1} S \mid\left\{\begin{array}{l}
\dot{q} \\
q
\end{array}\right. \\
I & 0
\end{array}\right| \\
& \dot{r} \\
& A
\end{aligned}
$$

gdzie $\mathbf{r}$ jest wektorem stanu o postaci: $r=\left\{\begin{array}{l}\dot{q} \\ q\end{array}\right\}$

a A macierzą stanu o postaci:

$$
A=\left|\begin{array}{cc}
-M^{-1} D & -M^{-1} S \\
I & 0
\end{array}\right|
$$

$\operatorname{dim} M=\operatorname{dim} S=\operatorname{dim} I=\operatorname{dim} O=n \times \mathrm{n}, \operatorname{dim} A=2 \mathrm{n} \times$ 2n, $\boldsymbol{I}, \boldsymbol{O}$ jest macierzą jednostkową i zerową.

Do postaci tej można sprowadzić każdy układ równań różniczkowych opisujący liniowy stacjonarny układ dynamiczny; przekształcenie odwrotne nie zawsze jest jednoznaczne. Znając warunki początkowe wektora stanu $q_{0} \quad$ i $\quad q_{0}$ można obliczyć zmiany, jakie będą 
and $\mathbf{A}$ is a matrix of state in the form of:

$$
A=\left|\begin{array}{cc}
-M^{-1} D & -M^{-1} S \\
I & 0
\end{array}\right|
$$

$\operatorname{dim} M=\operatorname{dim} S=\operatorname{dim} I=\operatorname{dim} 0=n \times \mathrm{n}, \operatorname{dim} A=2 \mathrm{n} \times$ 2n, $\boldsymbol{I}, \boldsymbol{O}$ is the unit and zero matrix.

To this form it can be brought any system of differential equations describing the stationary linear dynamic system; the inverse transformation is not always clear. Knowing the initial conditions of the state vector $q_{0}$ i $\dot{q}_{0}$ it can be calculated the changes that will take place for the time $t>t_{o}$ in this set. Achievement of a solution of the above equations in the analytical form, even for a few degrees of freedom, is difficult, laborious, and often practically impossible. Therefore, for the systems with many degrees of freedom, the numerical methods are commonly used to obtain their solutions.

Determining the matrix of state for any nonlinear sets of equations of motion at a point in time stored in the form of a set of non-linear equations:

$$
\dot{r}=A(t, r)
$$

can be made by calculating the Jacobi matrix:

$$
A(t)=J(t)=\left(\frac{\partial \tilde{A}_{i}}{\partial r_{j}}\right)=\left(\begin{array}{ccc}
\frac{\partial \tilde{A}_{1}}{\partial r_{1}} & \ldots & \frac{\partial \tilde{A}_{1}}{\partial r_{n}} \\
\ldots & \ldots & \ldots \\
\frac{\partial \tilde{A}_{n}}{\partial r_{1}} & \ldots & \frac{\partial \tilde{A}_{n}}{\partial r_{n}}
\end{array}\right)
$$

In order to obtain the elements of Jacobian matrix, in the computer programs for simulation of sets "multimass" the partial derivatives of their equations of motion must be determined. Often for this it is used the determination the difference quotients around the assumed for the calculations point in the space of state with coordinates $(t, r)$, including the assumed method of linearization of equations. One of the used methods of linearization is the perturbation method using increases of state variables around the starting point (plus-minus or unilaterally). Such an approach includes the effect of different model parameters, for example the non-linear hydraulic dampers, the friction elements (hysteresis), and also the parameters of the wheel-rail. Then in the linearization of equations it is considered a specific method of analysis of wheel-rail contact with the specific parameters of the profile of wheel and rail when moving on a straight line or along the curve at the set speed. However, it must be paid attention that the linearization of the model can be a source of significant inaccuracies of results of calculations.

By the way it can be added that Jacobian matrix is used in many different simulation issues, e.g.: zachodziły dla czasu $t>t_{o}$ w tym układzie. Uzyskanie rozwiązania powyższych równań $\mathrm{w}$ formie analitycznej, nawet dla kilku stopni swobody jest trudne, pracochłonne, a często praktycznie niemożliwe. Dlatego też dla układów o wielu stopniach swobody, do uzyskania ich rozwiązań, stosowane są powszechnie metody numeryczne.

Określenia macierzy stanu dla dowolnych nieliniowych układów równań ruchu w danej chwili czasu zapisanych $\mathrm{w}$ postaci układu równań nieliniowych:

$$
\dot{r}=\tilde{A}(t, r)
$$

dokonać można poprzez obliczenie macierzy Jacobiego:

$$
A(t)=J(t)=\left(\frac{\partial \tilde{A}_{i}}{\partial r_{j}}\right)=\left(\begin{array}{ccc}
\frac{\partial \tilde{A}_{1}}{\partial r_{1}} & \ldots & \frac{\partial \tilde{A}_{1}}{\partial r_{n}} \\
\ldots & \ldots & \ldots \\
\frac{\partial \tilde{A}_{n}}{\partial r_{1}} & \ldots & \frac{\partial \tilde{A}_{n}}{\partial r_{n}}
\end{array}\right)
$$

W celu uzyskania elementów macierzy Jacobiego, w programach komputerowych do symulacji układów „wielomasowych”, trzeba określić pochodne cząstkowe ich równań ruchu. Często do tego stosuje się wyznaczanie ilorazów różnicowych wokół przyjętego do obliczeń punktu w przestrzeni stanu o współrzędnych $(t, r), \mathrm{z}$ uwzględnieniem założonej metody linearyzacji równań. Jedną z stosowanych metod linearyzacji jest metoda perturbacji wykorzystująca przyrosty zmiennych stanu wokół punktu początkowego (plus-minus lub jednostronnie). Takie podejście obejmuje działanie różnych parametrów modelu, np. hydraulicznych thumików nieliniowych, elementów ciernych (histerezowych), a także parametrów koło-szyna. Wtedy w linearyzacji równań uwzględniana jest konkretna metoda analizy styku koło-szyna przy konkretnych parametrach profilu koła i szyny podczas poruszania się po prostej lub łuku z zadaną prędkością. Trzeba jednak mieć na uwadze, że linearyzacja modelu może być źródłem znacznych niedokładności wyników obliczeń.

$\mathrm{Na}$ marginesie można dodać, że macierz Jacobiego wykorzystywana jest $\mathrm{w}$ wielu różnych zagadnieniach symulacyjnych, np.:

- iteracyjnym obliczaniu kroku całkowania równań ruchu metodą implikowaną, np. Gear'a,

- linearyzacji równań ruchu,

- iteracyjnym obliczaniu warunków stacjonarnych,

- iteracyjnym rozwiązaniu implikowanych części modelu.

Przy wyznaczaniu parametrów drgań własnych dla zlinearyzowanego układu równań ruchu o postaci

$$
M \ddot{q}(t)+D \dot{q}(t)+S q(t)=0,
$$

gdzie macierze mas i sztywności są symetryczne: $\mathrm{M}=\mathrm{M}^{\mathrm{T}}, \mathrm{S}=\mathrm{S}^{\mathrm{T}}$, a macierz thumienia spełnia warunek $\mathrm{D}=\mathrm{D}^{\mathrm{T}}$, rozwiązanie jest o postaci: $\mathrm{q}=\mathrm{u} \mathrm{e}^{\lambda t}$ 
- iterative calculation of integration step of equations of motion with implied method e.g. Gear's,

- linearization of the equations of motion,

- iterative calculation of stationary conditions,

- iterative solution of implied parts of the model.

In determining the parameters of natural oscillation for the linearized set of equations of motion of the form

$$
M \ddot{q}(t)+D \dot{q}(t)+S q(t)=0,
$$

where the matrices of masses and stiffness are symmetric: $M=M^{T}, S=S^{T}$, a damping matrix meets the condition $\mathrm{D}=\mathrm{D}^{\mathrm{T}}$, the solution is in the form of: $\mathrm{q}=\mathrm{u} \mathrm{e}^{\lambda t}$ After replacing the matrix equation is obtained: $\left[\lambda^{2}\right.$ $\mathrm{M}+\lambda \mathrm{D}+\mathrm{S}] \mathrm{u}=0$, which can be converted to the form $\left(\begin{array}{cc}-M^{-1} D & -M^{-1} S \\ I & 0\end{array} \mid-\lambda I\right)\left\{\begin{array}{c}\lambda u \\ u\end{array}\right\}=0$, where: $\lambda, u$ are the complex numbers.

Finally, the above equation is in the form:

$$
\left(A-\lambda_{i} I\right)\left\{y_{i}\right\}=0 \text {, }
$$

whose the solution has $\mathrm{n}$ of natural oscillation values $\lambda_{i}$ and $\mathrm{n}$ of eigenvectors $\mathrm{y}_{\mathrm{i}}$. Determination of natural oscillation values and eigenvectors is done separately. Solutions of the above issue for $\mathrm{n}$ degrees of freedom is carried out numerically. One of the most effective methods is a QR method that uses the transformation of state matrix in the Hessenberg matrix. After determining the $m$ natural oscillation values in a separate numerical process the calculation of the eigenvectors corresponding to the natural values is carried out.
Po podstawieniu otrzymuje się równanie macierzowe: $\left[\lambda^{2} \mathrm{M}+\lambda \mathrm{D}+\mathrm{S}\right] \mathrm{u}=0$, które można przekształcić do postaci:

$\left(\begin{array}{cc}-M^{-1} D & -M^{-1} S \\ I & 0\end{array} \mid-\lambda I\right)\left\{\begin{array}{c}\lambda u \\ u\end{array}\right\}=0$, gdzie: $\lambda, u$ sa liczbami zespolonymi.

Ostatecznie powyższe równanie jest $\mathrm{w}$ postaci:

$$
\left(A-\lambda_{i} I\right)\left\{y_{i}\right\}=0,
$$

którego rozwiązanie posiada $\mathrm{n}$ wartości drgań własnych $\lambda_{\mathrm{i}}$ oraz $\mathrm{n}$ wektorów własnych $\mathrm{y}_{\mathrm{i}}$. Wyznaczanie wartości drgań własnych i wektorów własnych odbywa się odrębnie. Rozwiązania powyższego zagadnienia dla $n$ stopni swobody dokonuje się numerycznie. Jedną z najbardziej efektywnych metod jest metoda QR wykorzystująca przekształcenie macierzy stanu w macierz Hessenberga. Po wyznaczeniu $m$ wartości drgań własnych w odrębnym procesie numerycznym odbywa się obliczenie wektorów drgań własnych odpowiadających tym wartościom własnym.

Wynik obliczeń częstotliwości drgań własnych z systemów komputerowych ma postać:

$$
\begin{gathered}
s=-h \pm i \omega, \quad i=\sqrt{-1} \quad \omega_{0}=\sqrt{\omega^{2}+h^{2}} \\
\gamma=h / \omega_{0}
\end{gathered}
$$

i podawany jest przykładowo w postaci wydruku:

\begin{tabular}{|c|c|c|c|c|}
\hline Comple & ex eigenvalue & s in ascending & & \\
\hline & REAL & IMAGINARY & FREQUENCY & DAMPING \\
\hline gdzie & $\mathrm{h}$ & $\omega$ & $\omega_{0}$ & $\gamma$ \\
\hline 46 & -0.21639600 & & & \\
\hline 47 & -0.45360100 & & & \\
\hline $48-$ & -0.51754300 & $+/-2.87201000$ & 2.918270 & 0.177346 \\
\hline $50-$ & -1.42091000 & $+/-5.96385000$ & 6.130780 & 0.231766 \\
\hline $52-$ & -1.51068000 & $+/-6.72568000$ & 6.893260 & 0.219153 \\
\hline 54 & -1.53741000 & $+/-6.91708000$ & 7.085880 & 0.216968 \\
\hline $56-$ & -5.40887000 & $t /-6.56867000$ & 8.509010 & 0.635664 \\
\hline $58-$ & -1.56576000 & $t /-13.5953000$ & 13.68510 & 0.114413 \\
\hline $60-$ & -18.7075000 & & & \\
\hline $61-$ & -20.8366000 & & & \\
\hline $62-$ & -6.90357000 & $+/-20.1441000$ & 21.29430 & 0.324199 \\
\hline $64-$ & -6.48288000 & $+/-20.5987000$ & 21.59480 & 0.300206 \\
\hline $66-$ & -0.32124300 & $+/-22.9938000$ & 22.99600 & 0.013969 \\
\hline $68-$ & -16.2105000 & $t /-19.2032000$ & 25.13050 & 0.645053 \\
\hline $70-$ & -16.3971000 & $+/-19.2707000$ & 25.30270 & 0.648039 \\
\hline $72-$ & -19.2155000 & $+/-20.7990000$ & 28.31670 & 0.678593 \\
\hline $74-$ & -19.2135000 & $t /-20.8283000$ & 28.33690 & 0.678040 \\
\hline $76-$ & -3.73511000 & $+/-35.6262000$ & 35.82140 & 0.104270 \\
\hline $78-$ & -12.7221000 & $+/-34.9170000$ & 37.16250 & 0.342337 \\
\hline $80-$ & -11.5957000 & $+/-35.5102000$ & 37.35560 & 0.310416 \\
\hline
\end{tabular}
The result of calculations of natural oscillation frequencies from the computer systems has the form:

and is given for example in the form of a printout:

Number of maximally possible to determine the natural oscillation values is equal to the number of degrees of freedom of the dynamic system (the number of state variables), including "additional" non-mass degrees of freedom, e.g. deformation of serial elasticity of dampers. For the testing person the relatively small values of natural oscillation having the imaginary part $(\omega)$ are interesting the most frequently, as they reflect the real frequencies of
Fig. 2 Fragment of printout of natural oscillation frequencies Rys. 2 Fragment wydruku częstości drgań własnych 
oscillation of the rail vehicle. They are often reported as the angle frequency from which after dividing by $2 \cdot \pi$ the frequency in Hertz is received.

The eigenvectors of set obtained from the computer calculations are the extensive tables of complex numbers (column of real and imaginary part) with a number of the eigenvalue in the heading and the number of degrees of freedom (state variable) at the beginning of the line. The possibilities of manual analysis of such sets of numbers are very difficult. Therefore, the computer transformation of these tables and presentation of a set of natural oscillation values and eigenvectors e.g. in the form of "pie-phase " amplitude-phase charts is advantageous. In these charts the amplitude and angular position within each of the eigenvector are relative, but clearly defined. The sets of equations for the analysis of natural oscillation do not have a right side that is a defined enforcing, and this causes that the components of the eigenvector for the individual state variables belonging to the given value of frequency are not fully defined. This causes the a relative independence of the natural oscillation vectors characterizing in that:
Ilość maksymalnie możliwych do wyznaczenia wartości drgań własnych równa jest ilości stopni swobody układu dynamicznego (ilość zmiennych stanu), wliczając „dodatkowe” niemasowe stopnie swobody, np. deformacji szeregowej sprężystości tłumików. Interesujące dla badającego są najczęściej stosunkowo małe wartości drgań własnych posiadające część urojoną $(\omega)$, gdyż one obrazują realne częstotliwości drgań pojazdu szynowego. Podawane są one często jako częstotliwość kątowa, z której po podzieleniu przez $2 \bullet \pi$ otrzymuje się częstotliwość w Hertzach.

Wektory własne układu uzyskane z obliczeń komputerowych są obszernymi tablicami liczb zespolonymi (kolumna części rzeczywistej i części urojonej) z numerem wartości własnej $\mathrm{w}$ nagłówku i numerem stopnia swobody (zmiennej stanu) na początku wiersza. Możliwości analizy manualnej takich zbiorów liczbowych są bardzo trudne. Korzystne jest więc przekształcenie komputerowe tych tablic i przedstawienie zbioru wartości drgań własnych i wektorów własnych np. w postaci „kołowo-wskazowych” wykresów amplitudowo-fazowych. Na wykresach tych

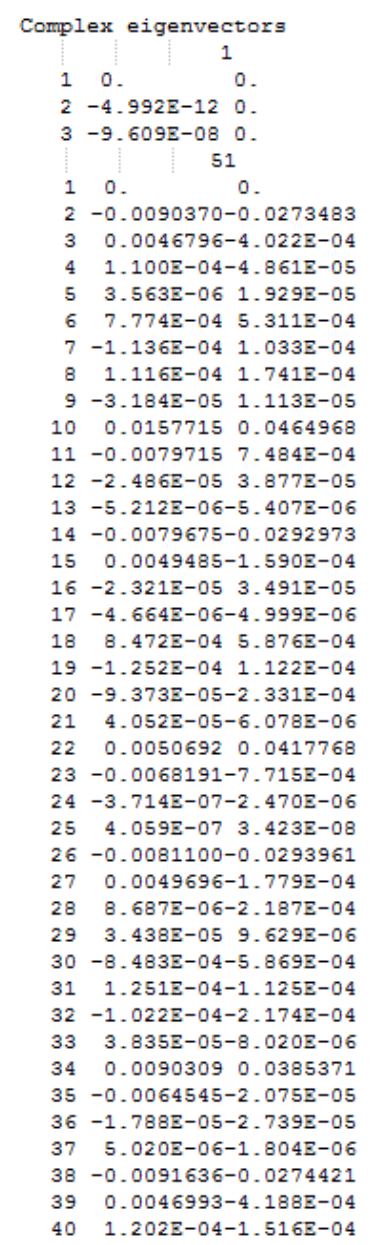

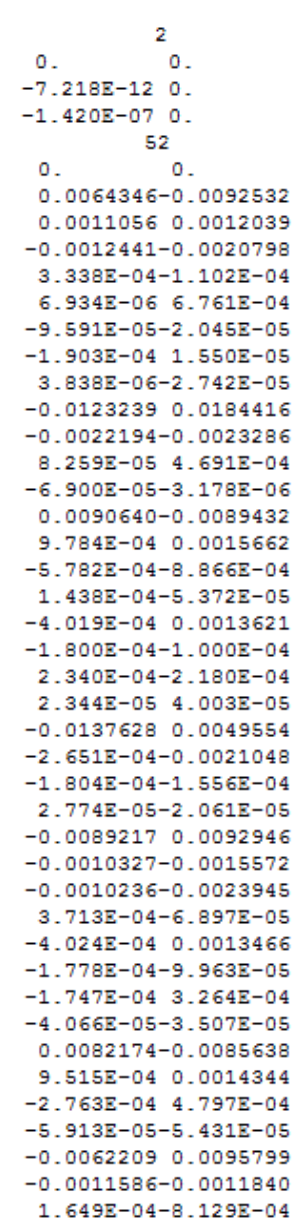

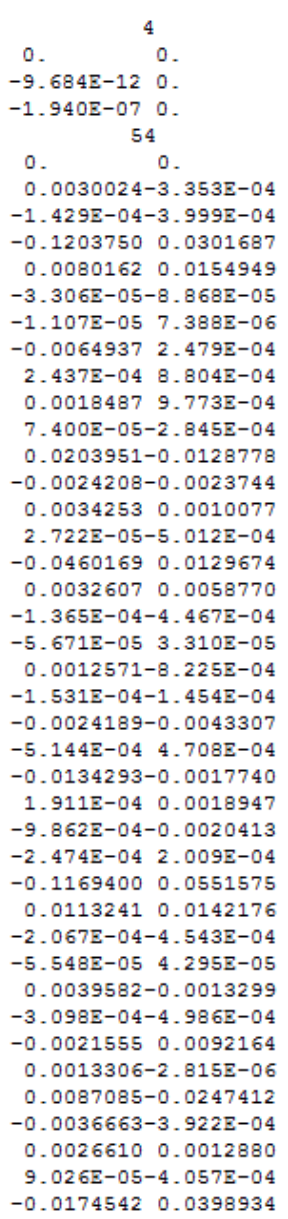

Rys. 3. Fragment wydruku wartości drgań własnych

Fig. 3. Fragment of printout of natural oscillation values 
- angular position and amplitude of the analyzed vector are undefined toward another vector,

- but the mutual relations of the length of vector components (normally standardized to the length of the maximum vector) are defined and the mutual angles between the individual components of the vector symbolizing the phase shift of the individual oscillation of the same eigenvalue are defined. Below the fragment of table containing the components of the eigenvector is shown as an example:

The process of developing the programs called postprocessors for creating the amplitude-phase charts (Fig. 2), which perfectly make assessment of natural oscillation vectors easier, is tedious but very effective at the end. In some developed computer systems other tools for the processing the natural oscillation values are developed, e.g. in the SIMPACK program the visualization of deformation of the vehicle structure by the motion animation is done. In the examples the results of the analyses of the natural oscillation values obtained by the authors in the MODKAT system (created in SIG Switzerland) are implemented.

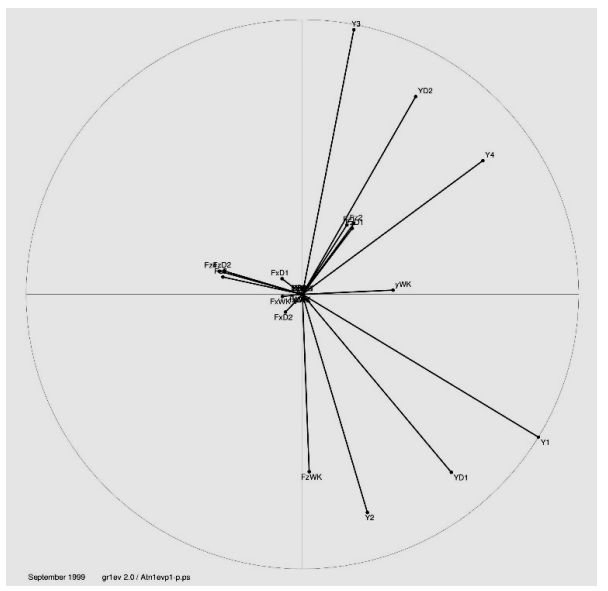

Fig. 4. Exemplary amplitude-phase chart for a form showing hunting of wagon's bogie: the actual profile of the wheel-rail with small conicity, speed of $1 \mathrm{~km} / \mathrm{h}$

Rys. 4. Przykładowy wykres amplitudowo-fazowy dla formy pokazującej wężykowanie wózka wagonu: rzeczywisty profil

koło-szyna o małej stożkowatości, prędkość jazdy $1 \mathrm{~km} / \mathrm{h}$

For the wagon body (with the correctly oriented axes, which is created mainly automatically): similar directions of motion vectors on the amplitude-phase chart represent the oscillation in the phase, e.g. vertical oscillation, and the opposite - pitching or nosing of the body. Compatible directions of lateral displacement of the wagon body with its nosing relative to its longitudinal axis means swaying I, and the opposite - swaying II. Oscillation of the body and bogies can be burdened with small mutual phase shifts caused by the action of dampers. Switching off the dampers should cause the lack of phase shift between the amplitudes (or the their occurrence in the counterphase). The larger phase shifts may indicate the mistakes in the model. amplituda i położenie kątowe w obrębie każdego wektora własnego mają charakter względny, lecz jednoznacznie określony. Układy równań do analizy drgań własnych nie posiadaja prawej strony, czyli zdefiniowanego wymuszenia, a to powoduje, że składowe wektora własnego dla poszczególnych zmiennych stanu należące do danej wartości częstotliwości własnej nie są w pełni określone. Powoduje to względną niezależność wektorów drgań własnych cechującą się tym, że:

- położenie kątowe i amplituda analizowanego wektora są nieokreślone względem innego wektora,

- natomiast określone są wzajemne relacje długości składowych wektora (normalnie normalizowane do długości maksymalnego wektora) oraz określone są kąty wzajemne między poszczególnymi składowymi wektora symbolizujące przesunięcie fazowe poszczególnych drgań o tej samej wartości własnej. Poniżej przykładowo pokazany jest fragmentu tabeli zawierającej składowe wektora własnego:

Proces opracowania programów zwanych postprocesorami, dla tworzenia wykresów amplitudowofazowych (rys.2), które znakomicie ułatwiają ocenę wektorów drgań własnych, jest żmudny ale na końcu bardzo efektywny. W niektórych rozwiniętych systemach komputerowych opracowano inne narzędzia do obróbki wartości drgań własnych, np. w programie SIMPACK wykonywana jest wizualizacja deformacji struktury pojazdu przez animację jej ruchu. W przykładach implementowano wyniki analiz wartości drgań własnych uzyskane przez autorów w systemie MODKAT (stworzonym w SIG Szwajcaria). Dla pudła wagonu (przy prawidłowo ukierunkowanych osiach, co tworzone jest przeważnie automatyczne): zbliżone kierunki wektorów ruchu na wykresie amplitudowo-fazowym oznaczają drgania w fazie, np. drgania pionowe, a przeciwstawne - pochylanie lub obracanie pudła. Zgodne kierunki przemieszczenia poprzecznego pudła wagonu $\mathrm{z}$ jego obrotem względem osi podłużnej oznacza kołysanie I, a przeciwstawne - kołysanie II. Drgania pudła i wózków obarczone mogą być niewielkimi wzajemnymi przesunięciami fazowymi spowodowanymi działaniem tłumików. Wyłączenie tłumików winno spowodować brak przesunięcia fazowego między amplitudami (lub występowanie ich w przeciwfazie). Większe przesunięcia fazowe mogą świadczyć o błędach w modelu.

Drgania kół: przemieszczenia poprzeczne, podłużne i obracanie wokół osi pionowej objawiają się wężykowaniem, a dla małych stożkowatości kół i nieco mniejszych prędkości jazdy - niestabilnością kierunkową. Bardzo charakterystyczne dla wężykowania jest względnie duże kątowe przesunięcie poszczególnych amplitud przemieszczeń postępowych względem 
The wheels oscillations: lateral, longitudinal displacements and nosing around a vertical axis show themselves in hunting, and for the small conicities of wheels and a slightly lower speeds of riding - directional instability. The relatively large angular displacement of individual amplitudes of progressive displacements relative to the rotational ones by about $90^{\circ}$ is very characteristic for hunting. It should be noted that the form of oscillation hunting is for any riding speed, only a value of damping coefficient indicates whether these oscillation occur in real (there will be hunting of vehicle or the vehicle will obtain a small directional stability). A small positive or negative damping coefficient of this own form indicates the unstable movement of the vehicle.

Natural oscillation frequencies are coupled comprehensively as shown in Fig. 5.

Many amplitude-phase charts can be grouped in one drawing, which is presented in Fig. 6. The numbers in the headings of these charts represent the own frequency and procentage dampings of the own form and the control number (insignificant). Small frequencies of natural oscillation in the picture are given in round figures, and the vectors of small lengths are not drawn. Names of vectors can be transposed for better readability on the names written in that language. The presented Fig. 6 shows the result of natural oscillation values of the exemplary wagon at a speed of $1 \mathrm{~km} / \mathrm{h}$. obrotowych o ok. $90^{\circ}$. Należy zwrócić uwagę, że postać drgań wężykowania występuje dla każdej prędkości jazdy, dopiero wartość współczynnika tłumienia wskazuje, czy drgania te wystapią w rzeczywistości (pojazd będzie wężykował lub uzyskiwał małą stabilność kierunkowa). Niewielki dodatni lub ujemny współczynnik tłumienia tej formy własnej wskazuje na niestabilny ruch pojazdu.

Częstotliwości drgań własnych są sprzężone kompleksowe, co uwidoczniono na rys. 5.
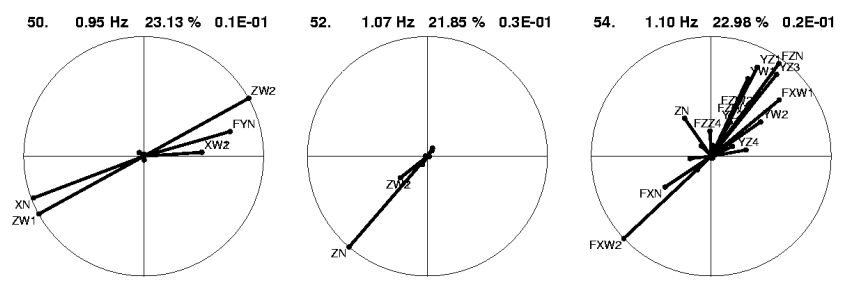

Fig. 5. Amplitude-phase charts of vectors of natural oscillation No $50 / 51,52 / 53,54 / 55$

Rys. 5. Wykresy amplitudowo-fazowe wektorów wartości drgań własnych $\mathrm{nr}$ 50/51, 52/53, 54/55

Wiele wykresów amplitudowo-fazowych można zgrupować na jednym rysunku, co przedstawiono na rys. 6. Liczby w nagłówkach tych wykresach przedstawiają częstotliwość własną i procentowe tumienia danej formy własnej oraz liczbę kontrolną (nieistotna). Małe częstotliwości drgań własnych są na rysunku podane $\mathrm{w}$ zaokrągleniu, a wektory o małych długościach nie są wykreślane. Nazwy wektorów mogą

\section{Coach 1cl. tare}

\section{Eigenvalues and eigenvectors}

config. normal, con. $0.2, v=1 \mathrm{~km} / \mathrm{h}$

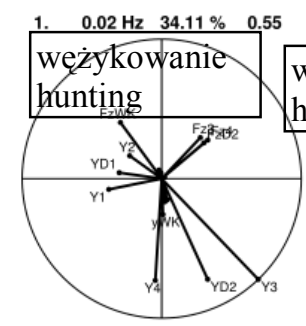

3. $0.02 \mathrm{~Hz} \quad 34.06 \% \quad 0.56$

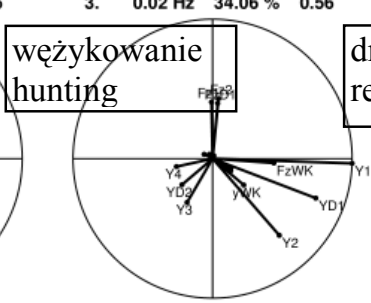

22. $\quad 1.07 \mathrm{~Hz} \quad 14.02 \% \quad 0.13$

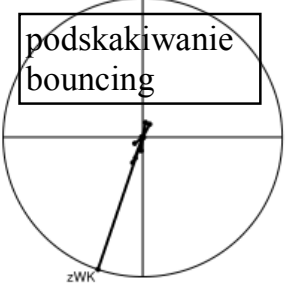

41. $11.43 \mathrm{~Hz} \quad 16.94 \% \quad 7.69 \mathrm{E}-03$

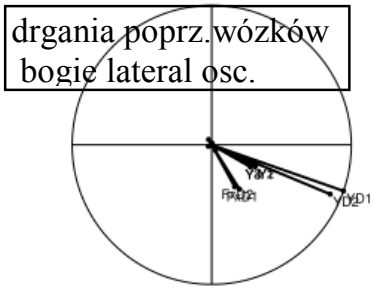

25. $1.11 \mathrm{~Hz} \quad 15.74 \% \quad 0.32$

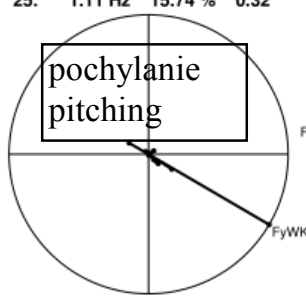

43. $11.43 \mathrm{~Hz} \quad 16.98 \% \quad 7.68 \mathrm{E}-03$

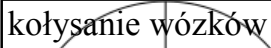

bogie swaying

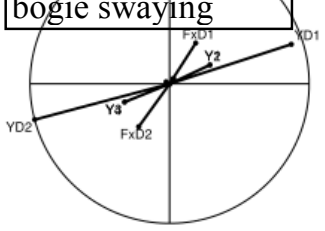

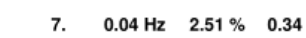

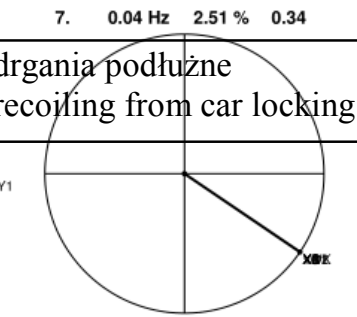

27. $\quad 1.36 \mathrm{~Hz} \quad 26.95 \% \quad 9.07 \mathrm{E}-02$

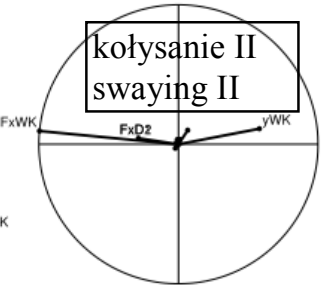

45. $\quad 12.32 \mathrm{~Hz}_{2} 37.44 \% \quad 7.89 \mathrm{E}-03$

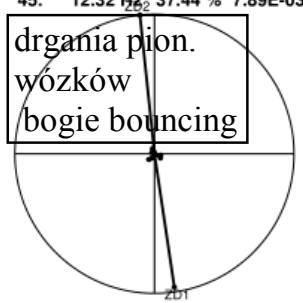

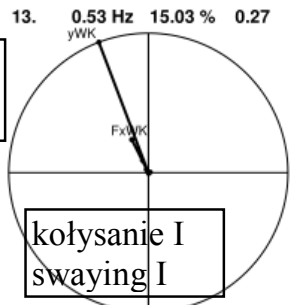
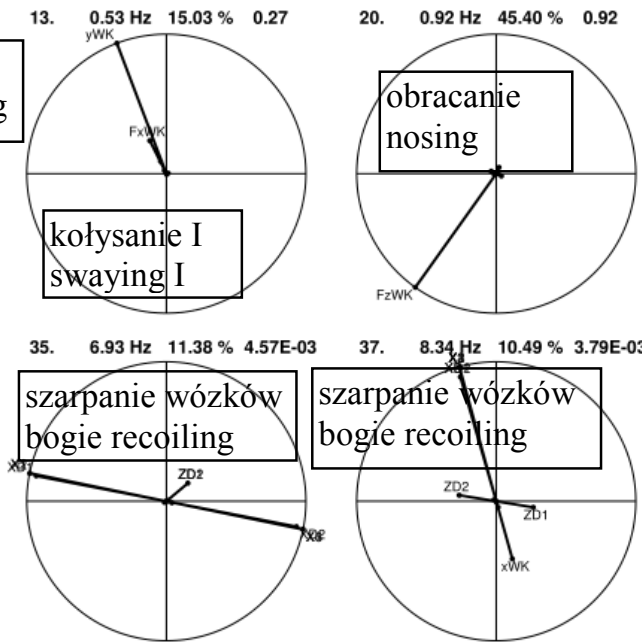

47. $\quad 12.33 \mathrm{~Hz} \quad 37.47 \% \quad 7.87 \mathrm{E}-03$

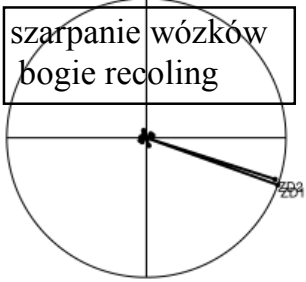

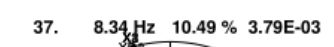

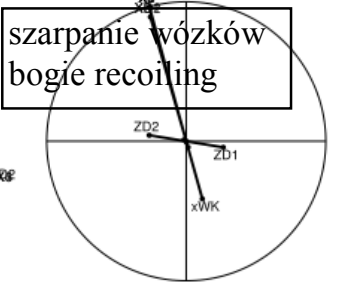

49. $\quad 16.07 \mathrm{~Hz} \quad 28.29 \% \quad 5.00 \mathrm{E}-03$
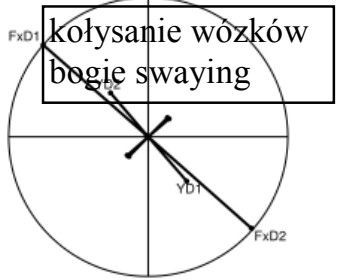

Fig. 6. Exemplary lowest own frequencies of passenger wagon Rys. 6. Przykładowe najmniejsze częstości własne wagonu osobowego 

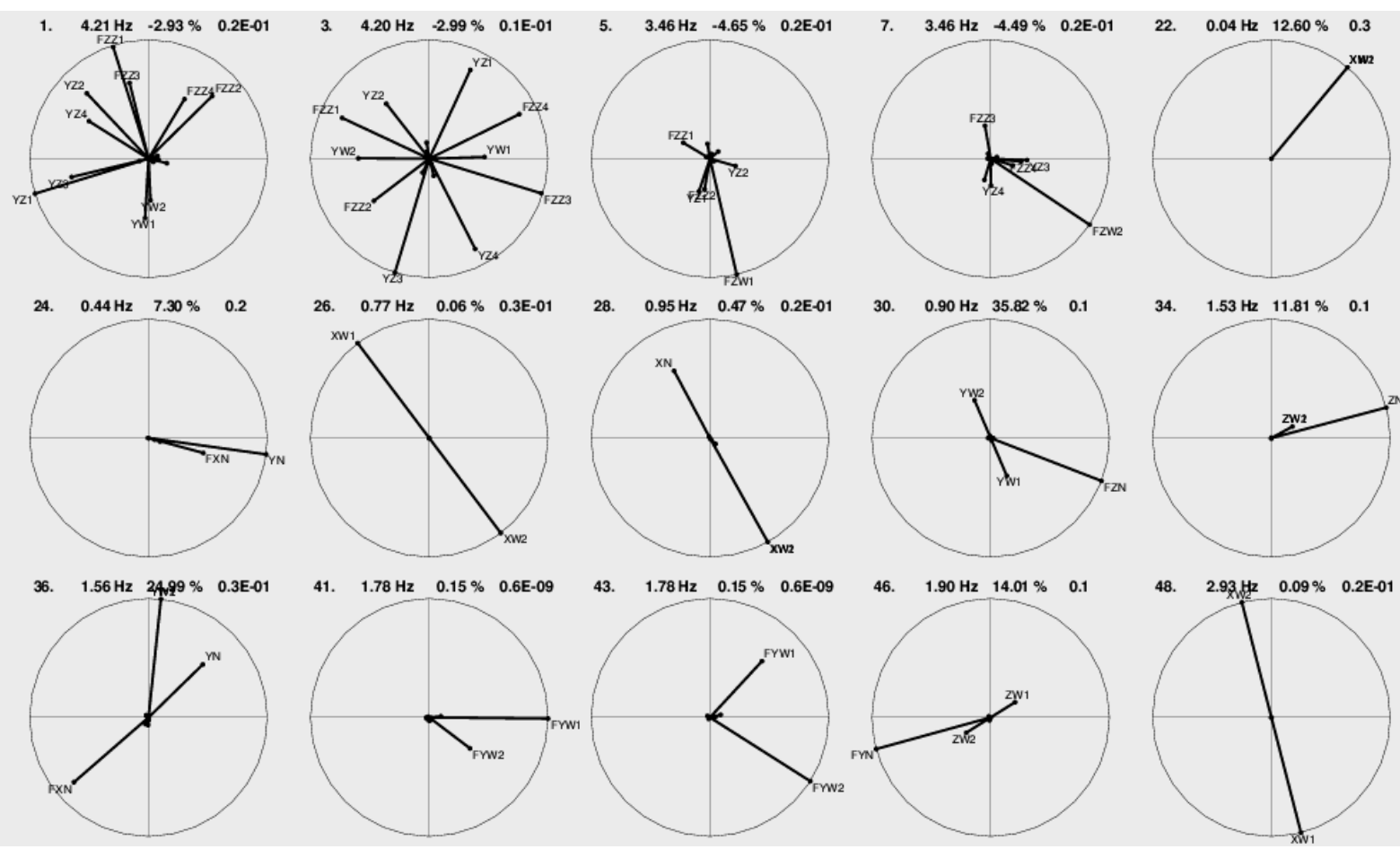

Fig. 7. Result of amplitude-phase analysis of exemplary control wagon moving unstable at a speed of $100 \mathrm{~km} / \mathrm{h}$ [2]

Rys. 7. Wynik analizy amplitudowo-fazowej przykładowego poruszającego się niestabilnie wagonu sterowniczego przy prędkości $100 \mathrm{~km} / \mathrm{h}$ [2]

Figure 7 shows the result of frequency-phase analysis for small frequencies of the exemplary wagon at a speed of $100 \mathrm{~km} / \mathrm{h}$, which is unstable at this speed.

In the analysis of rail vehicles properties, the calculated eigenvalues are used as:

- sets of circular amplitude-phase charts for the individual forms of oscillation (Fig. 2);

- charts of "root lines" (Fig. 3, 4) obtained from the sequence of eigenvalues in a function of any changeable parameter in the model (e.g. speed);

- stability cards built on basis of many charts of root lines.

\section{RESULTS OF NATURAL OSCILLATION ANALYSES}

Analyses of individual forms of natural oscillation allow the following approximate interpretation of the form of these oscillation in the range:

- comparisons of the main frequency of natural oscillation of vehicle forecasting, at the design stage of its riding, calmness and comfort for the service;

- selection of the optimum parameters of the vehicle to ensure the stability of the vehicle;

- by switching off the operation of dampers and springs it can be analyzed the impact of emergency states and parameter changes on the behavior of the vehicle dynamics;

- correctness of the vehicle model construction - the more accurate analysis of the form of natural oscillation gives a chance to identify the possible errors of the vehicle modeling, which is very important for accuracy of simulation considerations. być transponowane dla lepszej czytelności na nazwy napisane $\mathrm{w}$ danym języku. Zaprezentowany rys. 6 przedstawia wynik wartości drgań własnych przykładowego wagonu przy prędkości jazdy $1 \mathrm{~km} / \mathrm{h}$.

$\mathrm{Na}$ rysunku 7 przedstawiono wynik analizy częstotliwościowo-fazowej dla małych częstotliwości przykładowego wagonu przy prędkości $100 \mathrm{~km} / \mathrm{h}$, który przy tej prędkości jest już niestabilny.

W analizie właściwości pojazdów szynowych, obliczone wartości własne wykorzystuje się jako:

- zbiory kołowych wykresów amplitudowo-fazowych dla poszczególnych postaci drgań (rys.2)

- wykresy „linii pierwiastkowych” (rys.3, 4) uzyskane z ciagów wartości własnych w funkcji jakiegoś parametru zmiennego w modelu (np. prędkości jazdy)

- karty stabilności zbudowane na bazie wielu wykresów linii pierwiastkowych.

\section{WYNIKI ANALIZ DRGAŃ WLASNYCH}

Analizy form poszczególnych drgań własnych pozwalają na następująca przybliżoną interpretacje postaci tych drgań w zakresie:

- porównania głównych częstotliwości drgań własnych pojazdu, prognozującego na etapie projektu jego spokojności jazdy i komfort dla obsługi;

- wybór optymalnych parametrów pojazdu dla zapewnienia stabilności ruchu pojazdu;

- przez wyłączenie działania tłumików i sprężyn można przeanalizować wpływ stanów awaryjnych i zmian parametrów na zachowanie się dynamiki pojazdu; 
Determination of the frequency of natural oscillation of the vehicle is made mostly for small speeds, and the assessments of stability for sufficiently large speeds of the modeled vehicle.

To discern the frequencies of natural oscillation of the wagon it is shown the results obtained for the exemplary 4-axis wagon, which is considered as a comfortable wagon (in the range of dynamic).

Częstotliwości drgań własnych przykładowego wagonu 4osiowego

Frequencies of natural oscillation of the exemplary 4-axis wagon Tabela 1/Table 1

\begin{tabular}{|l|l|l|}
\hline $\begin{array}{l}\text { typ drgań/type of } \\
\text { oscillation }\end{array}$ & $\begin{array}{l}\text { częstość [Hz]/ } \\
\text { frequency [Hz] }\end{array}$ & $\begin{array}{l}\text { thumienie [\%] } \\
\text { damping [\%] }\end{array}$ \\
\hline $\begin{array}{l}\text { Drgania pionowe } \\
\text { /vertical oscillation }\end{array}$ & 1,07 & 14,00 \\
\hline kołysanie I/swaying I & 0,53 & 15,02 \\
\hline $\begin{array}{l}\text { kołysanie II/swaying } \\
\text { II }\end{array}$ & 1,39 & 25,70 \\
\hline Pochylanie/pitching & 1,11 & 15,75 \\
\hline Obracanie/nosing & 1,04 & 43,25 \\
\hline
\end{tabular}

\section{ROOT LINES OF OWN FREQUENCIES COURSE}

Root lines are another representation of the group of eigenvalues with one variable, e.g. speed. They allow to present in one single complex figure:

- identification of the trends and the influence of parameters on the natural oscillation of vehicle;

- presentation of the course of natural oscillation frequencies and damping decrement, e.g. as a function of speed

- finding the coupling forms of oscillation.

The graph is obtained from a large number of individual results of calculations of eigenvalues, e.g. for several dozen speeds of the vehicle. For one graph it is usually taken one linear conicity of wheels. Most of the calculated eigenvalues do not changes much with the speed variability of the vehicle. However, the damping coefficients of wheelset hunting or the directional instability are strongly variable in the function

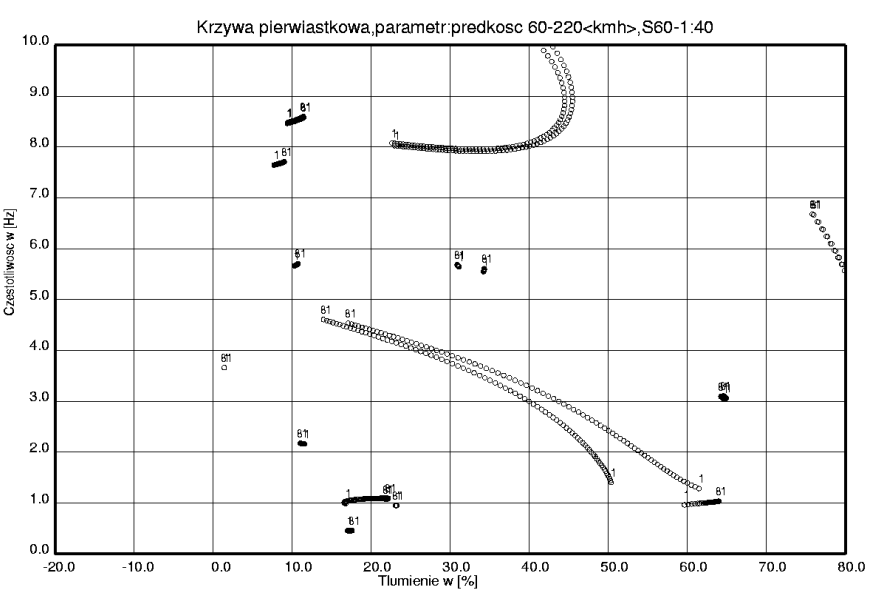

Fig. 8. Root lines (eigenvalues) frequency in damping function. Rys. 8. Linie pierwiastkowe (wartości własne) częstotliwość w funkcji thumienia.
- poprawności budowy modelu pojazdu - dokładniejsza analiza postaci drgań własnych daje szanse wykrycia ewentualnych błędów modelowania pojazdu, co ma bardzo duże znaczenie dla rzetelności rozważań symulacyjnych.

Określenie częstotliwości drgań własnych pojazdu dokonuje się najczęściej dla małych prędkości jazdy, a oceny stabilności dla odpowiednio dużych prędkości jazdy modelowanego pojazdu.

Dla rozeznania częstotliwości drgań własnych wagonu przedstawiono wyniki uzyskane dla przykładowego wagonu 4-osiowego, uznawanego za wagon komfortowy (w zakresie dynamiki).

\section{LINIE PIERWIASTKOWE PRZEBIEGU CZĘSTOTLIWOŚCI WLASNYCH}

Linie pierwiastkowe są innym przedstawieniem grupy wartości własnych z jedną zmienną, np. prędkością jazdy. Pozwalają na przedstawienie na jednym złożonym rysunku:

- określenie trendów i wpływu parametrów na drgania własne pojazdu;

- pokazanie przebiegu częstotliwości drgań własnych i dekrementu thumienia np. w funkcji prędkości;

- znalezienie sprzęgających się postaci drgań.

Wykres otrzymuje się z dużej liczby pojedynczych wyników obliczeń wartości własnych, np. dla kilkudziesięciu prędkości jazdy pojazdu. Dla jednego wykresu przeważnie przyjmuje się jedną liniową stożkowatość kół. Większość obliczonych wartości własnych niewiele zmienia się wraz ze zmiennością prędkości jazdy pojazdu. Mocno zmienne w funkcji prędkości są natomiast współczynniki tłumienia wężykowania zestawów kołowych lub niestabilność kierunkowej. Ta silna zmienność jest głównym celem tworzenia tych interesujących wykresów. Celem dodatkowym jest często możliwość wykrycia sprzęgających się postaci drgań własnych objawiających się dużą zmiennością wartości (częstotliwości i dekrementu tłumienia) oraz

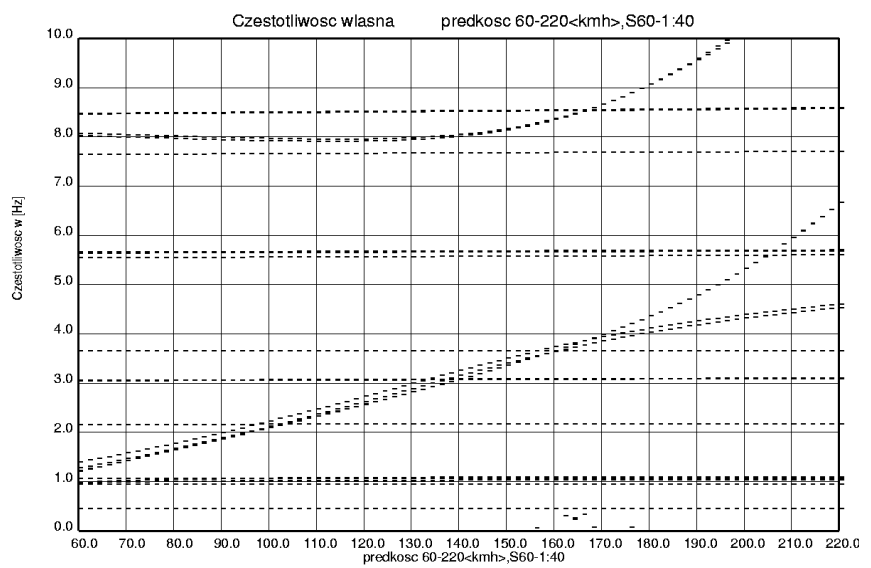

Fig. 9. Root lines (frequencies of natural oscillations) frequency in speed function

Rys. 9. Linie pierwiastkowe (częstotliwości drgań własnych) częstotliwość w funkcji prędkości jazdy 
of speed. This strong variability is the main purpose of creating these interesting graphs. An additional aim is often the possibility of detection the coupling forms of natural oscillation showing the high variability of values (frequency and damping decrement) and form of natural oscillation in the function of speed. This phenomenon can cause the significant deterioration of running characteristics of the vehicle. Below the examples of various course of the root lines are presented in Fig. 8 and 9 for the actual profile of wheelrail, and in Fig. 10 and 11 for the equivalent conicity.

\section{Eigenvalues analyse}

IR-Coach $1 \mathrm{cl}$. tare

Car normal, conicity 0.05
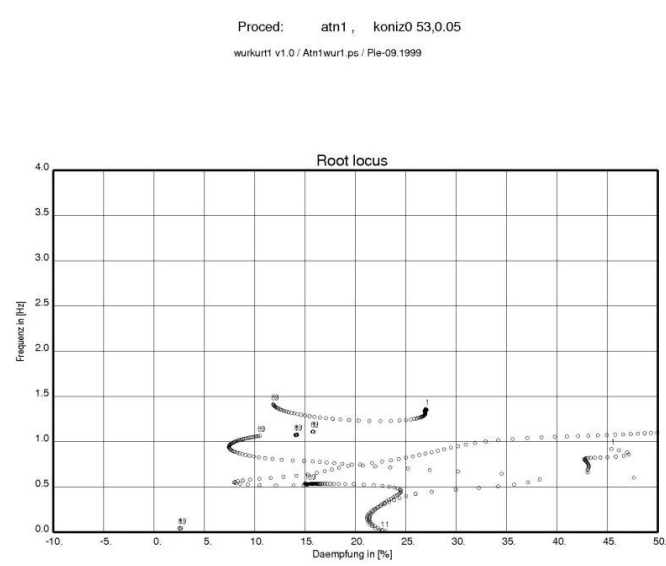

postaci drgań własnych w funkcji prędkości jazdy. Zjawisko to może spowodować znaczne pogorszenie właściwości biegowych pojazdu. Poniżej przedstawiono przykłady różnego przebiegu linii pierwiastkowych, na rys. 8 i 9 dla rzeczywistego profilu kołoszyna, a na rys, 10 i 11 dla stożkowatości ekwiwalentnej.
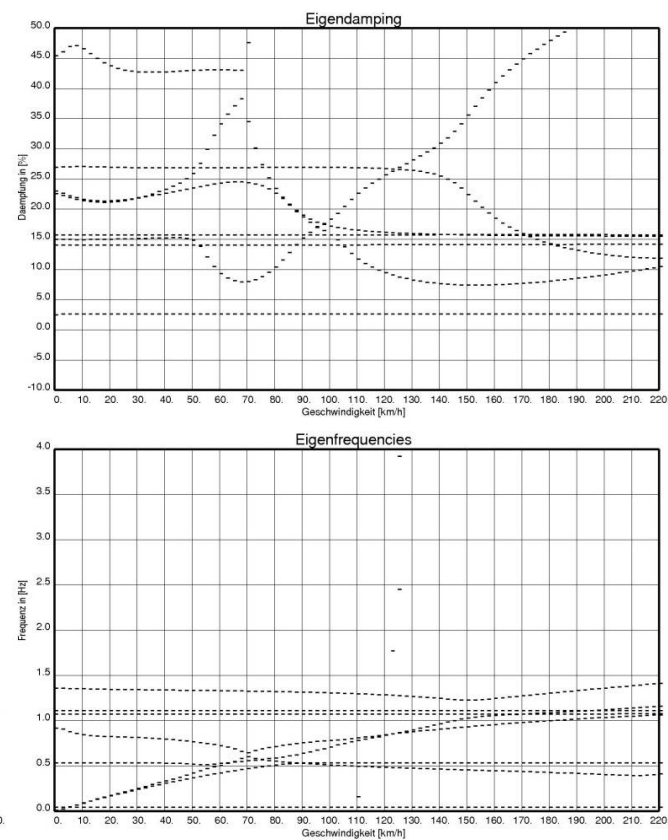

Fig. 10. Exemplary root lines in a function of speed at very small conicity of wheel-rail, the hunting instability is not reached, the visible slight coupling of oscillation (high nonlinearity of arrangement of subsequent points of own frequencies) and a small directional stability.

Rys. 10. Przykładowe Linie pierwiastkowe w funkcji prędkości jazdy przy bardzo małej stożkowatości koło-szyna, nie osiągnięto niestabilności wężykowania, widoczne niewielkie sprzężenie drgań (duża nieliniowość uszeregowania kolejnych punktów częstotliwości własnych) i niewielka stabilność kierunkowa

Eigenvalues analyse

IR-Coach $1 \mathrm{cl}$. tare

Car normal, conicity 0.6

$$
\text { Proced: atn1, koniz0 53,0.6 }
$$
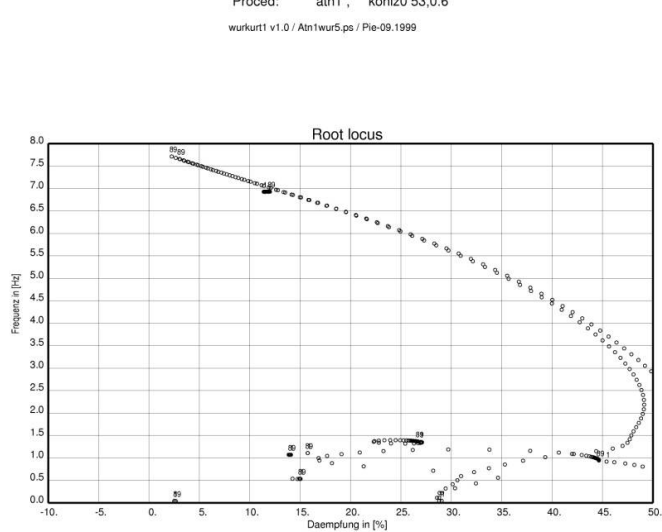
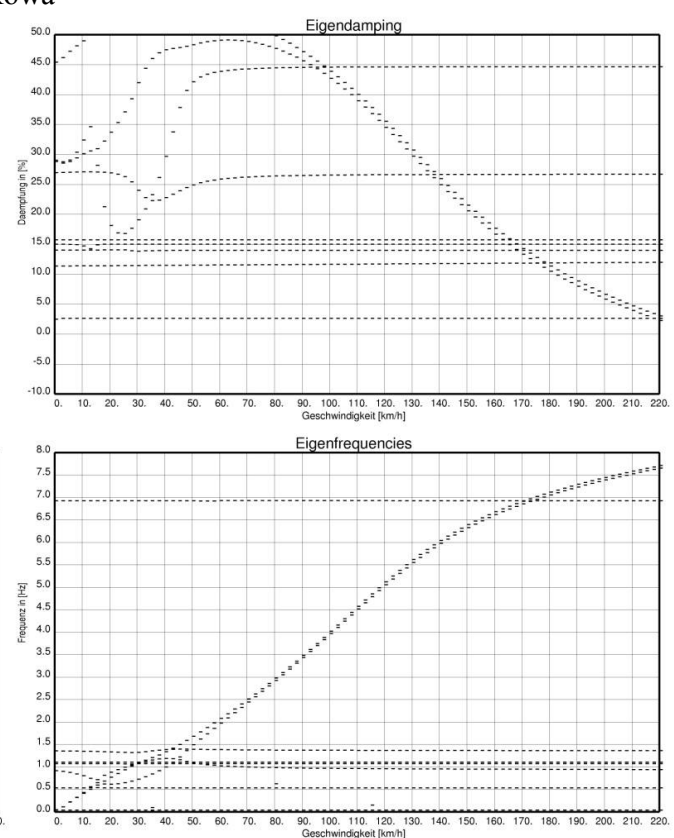

Fig.11 Exemplary root lines in a function of speed at very big conicity of wheel-rail, the wagon is almost unstable at a speed of $220 \mathrm{~km} / \mathrm{h}$, it has a non-threatening coupling of oscillation at speeds of $10-50 \mathrm{~km} / \mathrm{h}$

Rys.11 Przykładowe linie pierwiastkowe w funkcji prędkości jazdy przy znacznej stożkowatości koło-szyna, wagon jest prawie niestabilny przy prędkości $220 \mathrm{~km} / \mathrm{h}$, posiada niegroźne sprzężenie drgań przy prędkościach jazdy $10-50 \mathrm{~km} / \mathrm{h}$ 


\section{CARD OF STABILITY}

The last type of implementation of the results of natural oscillation values is a card of stability. It is made up of many (several dozen) root lines by searching them for finding the points of the given value of damping of hunting (or directional stability). It is the most developed form of analysis of vehicle model, it is possible to create it by searching the entire area of potential hunting or performing procedures to automate, so that the process is difficult and onerous.

The chart is created by the lines of equal, specific value of attenuation of frequency of vehicle hunting in the function of speed and in the function of the conicity of wheel-rail system. It allows e.g. to quickly assess the impact of design changes on the vehicle's behavior in the whole spectrum of speed and wheelrail conicity.

Connecting the stability card with the information on the possible occurrence of the coupling of oscillation in this vehicle and occurring on the railway line the maximum equivalent conicity allows in a quick way to determine the initial running properties of vehicle (for comparison the required conicities for the hypothetical maximum speed of stable vehicle riding on this track according to EN 14363 are presented in Table 2)

Table 2. Maximum equivalent conicities that can occur on the railway lines [4]

Tabela 2. Maksymalne ekwiwalentne stożkowatości jakie mogą wystąpić na liniach kolejowych [4]

\begin{tabular}{|c|c|}
\hline Lokalnie dopuszczalna prędkość & Ekwiwalentna stożkowatość tan $\gamma_{\epsilon}$ \\
\hline $\mathrm{v} \leq 140 \mathrm{~km} / \mathrm{h}$ & $\leq 0,5$ \\
\hline $140 \mathrm{~km} / \mathrm{h}<\mathrm{v} \leq 200 \mathrm{~km} / \mathrm{h}$ & $\leq 0,4$ \\
\hline $200 \mathrm{~km} / \mathrm{h}<\mathrm{v} \leq 220 \mathrm{~km} / \mathrm{h}$ & $\leq 0,35$ \\
\hline $220 \mathrm{~km} / \mathrm{h}<\mathrm{v} \leq 250 \mathrm{~km} / \mathrm{h}$ & $\leq 0,3$ \\
\hline $250 \mathrm{~km} / \mathrm{h}<\mathrm{v} \leq 280 \mathrm{~km} / \mathrm{h}$ & $\leq 0,25$ \\
\hline $280 \mathrm{~km} / \mathrm{h}<\mathrm{v} \leq 350 \mathrm{~km} / \mathrm{h}$ & $\leq 0,15$ \\
\hline
\end{tabular}

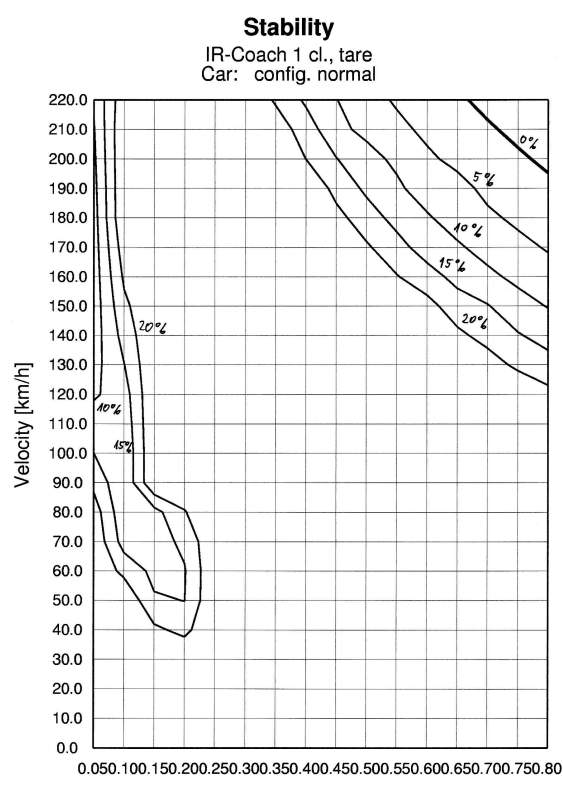

Conicity
Fig. 12. Stability cards of exemplary passenger wagon in the normal configuration [own elaboration]

Rys. 12. Karty stabilności przykładowego wagony osobowego w konfiguracji normalnej [oprac. własne]

\section{KARTA STABILNOŚCI}

Ostatnim typem implementacji wyników wartości drgań własnych jest karta stabilności. Tworzona jest $\mathrm{z}$ wielu (kilkudziesięciu) linii pierwiastkowych przez przeszukanie ich dla znalezienia punktów o danej wartości thumienia wężykowania (lub stabilności kierunkowej). Jest to najbardziej rozwinięta forma analizy modelu pojazdu, możliwa do utworzenia przez przeszukanie całego obszaru potencjalnego wężykowania lub wykonanie procedur automatyzujących tak i tak jest to proces trudny i uciążliwy.

Wykres tworzą linie równej, określonej wartości thumienności częstotliwości wężykowania pojazdu w funkcji prędkości jazdy i w funkcji stożkowatości układu koła-szyna. Pozwala ona np. szybko ocenić wpływ zmian konstrukcji na zachowanie pojazdu w całym spektrum prędkości jazdy i stożkowatości kołoszyna.

Łącząc kartę stabilności z informacjami o ewentualnym występowaniu sprzężenia drgań w tym pojeździe i o występującej na danej linii kolejowej maksymalnej ekwiwalentnej stożkowatości pozwala w szybki sposób określić wstępnie właściwości biegowe pojazdu (dla porównania przedstawiono $\mathrm{w}$ tabeli 2 wymagane wg. normy EN 14363 stożkowatości dla hipotetycznej prędkości maksymalnej stabilnego pojazdu poruszającego się na tym torze.

$\mathrm{Na}$ rysunkach 12 i 13 przedstawiono przykłady kart stabilności.

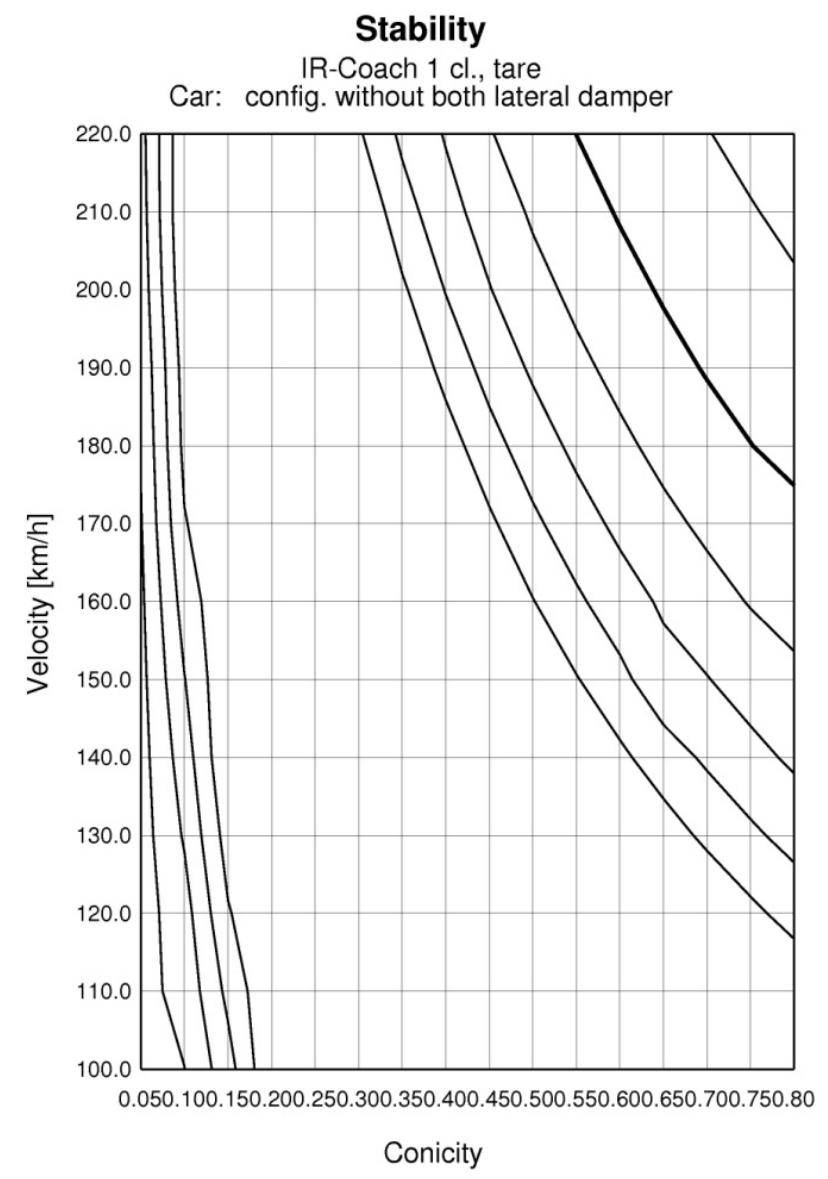


In the figures 12 and 13 the examples of stability cards are presented.

\section{LIMIT CYCLES}

A separate method of determining the stability of the vehicle is the course of the behavior of the model during the simulation after time. So, it is not a matrix analysis of natural oscillation values. The model can be fully non-linear, i.e. having no simplifications required for the linear analysis. Such a model is more accurate, but the conclusions of the simulations are less general. The presented method is presented in an article for the comparison with the matrix methods for determining the natural oscillation.

To determine the course of limit cycles, the simulation in the course of a "multi" type, whose results are presented in a single graph, is made most frequently. Each fragment of the course is made for one constant speed of riding (usually arranged increasingly). The simulation courses are short (for example $4 \mathrm{sec}$ are enough). At the beginning of each course of the initial movement of the vehicle towards the track in the lateral direction is made to observe the lateral oscillation of the vehicle during the simulation.
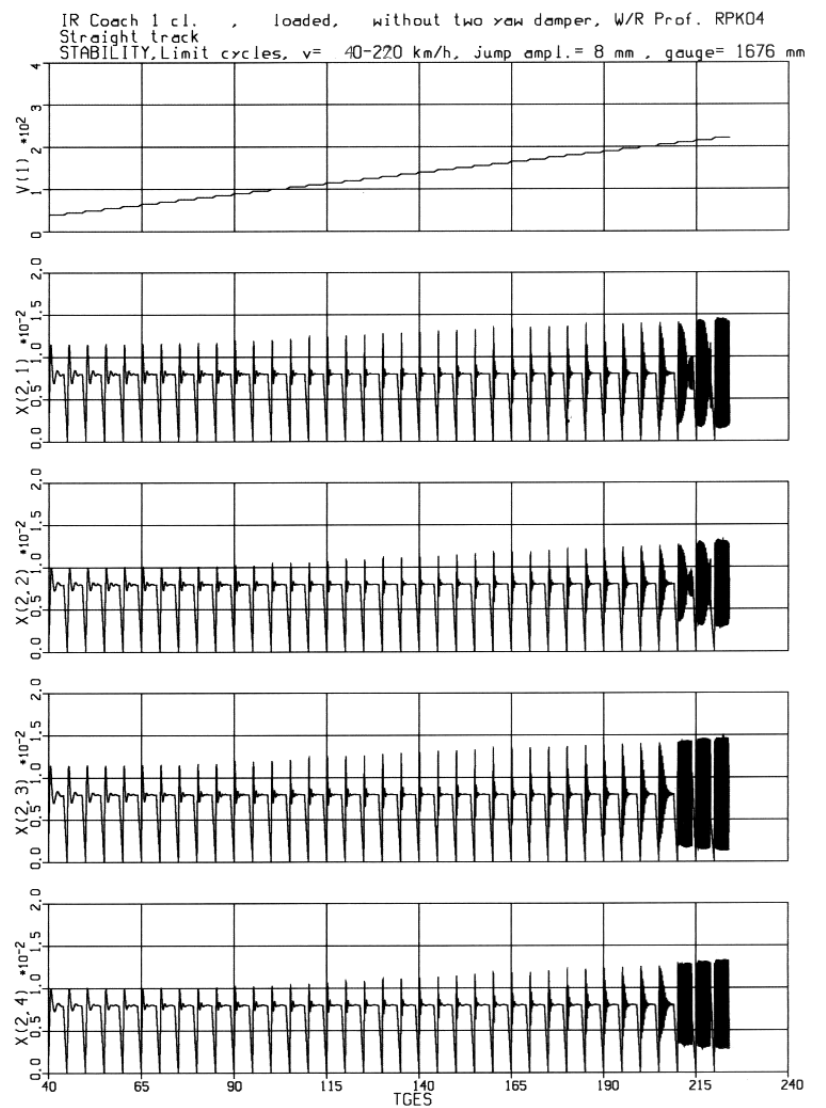

Fig. 14. Limit cycles. Graphs of lateral movements of wheelsets, the stroke amplitude of $8 \mathrm{~mm}$. 4-axle passenger wagon, unstable from $210 \mathrm{~km} / \mathrm{h}$, the full instability appears at first on the second bogie

Rys. 14. Cykle graniczne, Wykresy przemieszczeń poprzecznych zestawów kołowych, amplituda skoku $8 \mathrm{~mm}$. Wagon 4-osiowy pasażerski, niestabilny od $210 \mathrm{~km} / \mathrm{h}$, niestabilność pełna pojawia się najpierw na drugim wózku

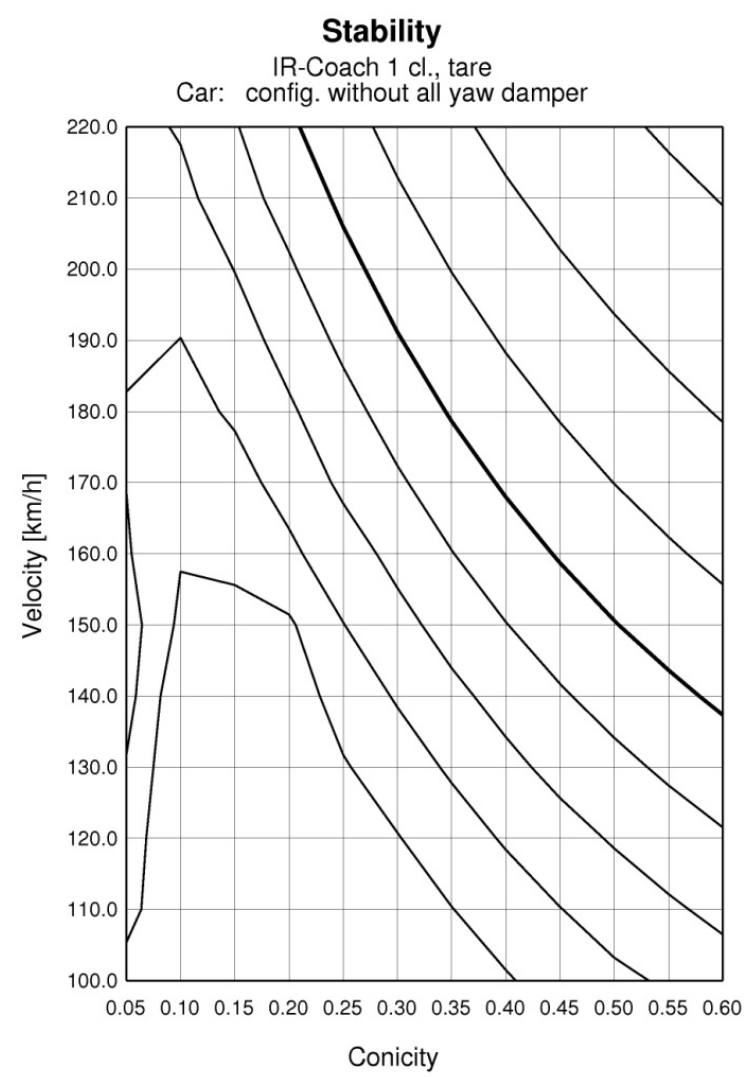

Fig. 13. Stability cards of the exemplary passenger wagon with switched off lateral dampers or switched off dampers of hunting, the figures include the various ranges of analyses

Rys. 13. Karty stabilności przykładowego wagonu osobowego z wyłączonymi tłumikami poprzecznymi lub z wyłączonymi thumi-

kami wężykowania, rysunki obejmują różne zakresy analiz

\section{CYKLE GRANICZNE}

Odrębną metodą określenia stabilności pojazdu jest przebieg zachowania się modelu w czasie symulacji po czasie. Nie jest to więc macierzowa analiza wartości drgań własnych. Model może być w pełni nieliniowy, tj. nie posiadający uproszczeń wymaganych do analizy liniowej. Model taki jest dokładniejszy, ale wnioski z jego symulacji są mniej ogólne. Przedstawiona metoda została zaprezentowana w artykule dla porównania $\mathrm{z}$ macierzowymi metodami wyznaczania drgań własnych.

Dla określenia przebiegu cykli granicznych dokonuje się najczęściej symulacyjnie w przebiegu typu „multi”, którego wyniki są przedstawiane na jednym wykresie. Każdy fragment przebiegu dokonywany jest dla jednej stałej prędkości jazdy (przeważnie uszeregowanej wzrastająco). Przebiegi symulacyjne są krótkie (wystarczające są np. 4 sek.). Na początku każdego przebiegu dokonuje się początkowego przesunięcia pojazdu względem toru $\mathrm{w}$ kierunku poprzecznym w celu zaobserwowania poprzecznych drgań pojazdu w czasie symulacji. 
The vehicles with wheelsets during the simul,ation after the time after the starting of displacement, move spontaneously oscillating around the line of track centre. For the stable vehicle this movement is disappearing to the centre position, and for the unstable vehicle the movement is unstable, nondisappearing, ending with the movement with nearly constant amplitude (limit cycle). Stability depends on the speed of riding and the local conicity of wheels. The individual wheelsets behave differently, usually the rear wheelsets are more unstable.

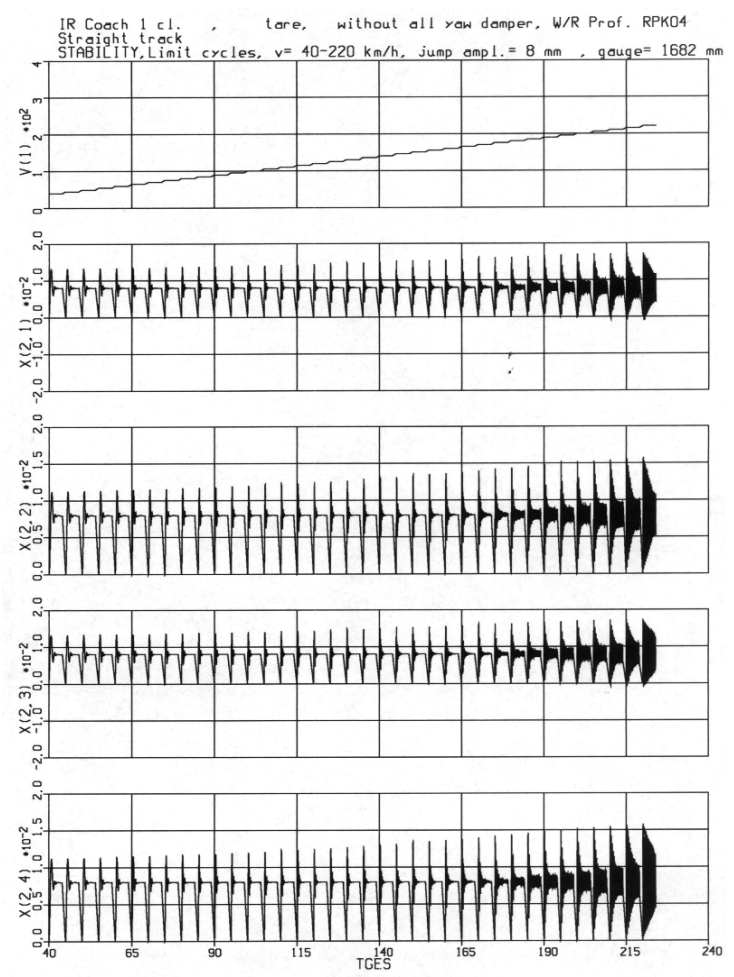

Fig. 16. Limit cycles. Graphs of lateral movements of wheelsets. The instability with small amplitude caused by the local high conicity due to a jump of contact point of wheel-rail, appearing from approx. $180 \mathrm{~km} / \mathrm{h}$, the riding is not dangerous to approx. $220 \mathrm{~km} / \mathrm{h}$, but deteriorating unacceptably the comfort of riding

Rys. 16. Cykle graniczne, Wykresy przemieszczeń poprzecznych zestawów kołowych. Niestabilność o niewielkiej amplitudzie, spowodowana lokalną dużą stożkowatością spowodowaną przeskokiem punktu styku koło-szyna, pojawiająca się od ok. 180 $\mathrm{km} / \mathrm{h}$, jazda nie jest niebezpieczna do ok. $220 \mathrm{~km} / \mathrm{h}$, ale pogarszająca niedopuszczalnie komfort jazdy

\section{SUMMARY}

The presented in the publication different methods of advanced analysis of natural oscillation of mathematical models of rail vehicles are not very widespread, and often even not applied in popularly used simulation systems. A detailed simulation analysis of the behavior of vehicles (especially untypical) sometimes requires the combined using of several presented methods. In the case of detecting the irregularities of the construction on the phase of project, it allows for their modification. Detection of these irregularities later (on the prototype phase) is connected with more expensive tests of this prototype.
Pojazdy z zestawami kołowymi w czasie symulacji po czasie po początkowym przesunięciu poruszają się samoistnie ruchem oscylacyjnym wokół linii środka toru. Dla pojazdu stabilnego ruch ten jest zanikający do położenia środkowego, a dla pojazdu niestabilnego ruch jest niestabilny niezanikający, kończący się ruchem o prawie stałej amplitudzie (cykl graniczny). Stabilność zależy od prędkości jazdy i lokalnej stożkowatości kół. Poszczególne zestawy kołowe zachowują się różnie, przeważnie tylne są bardziej niestabilne.
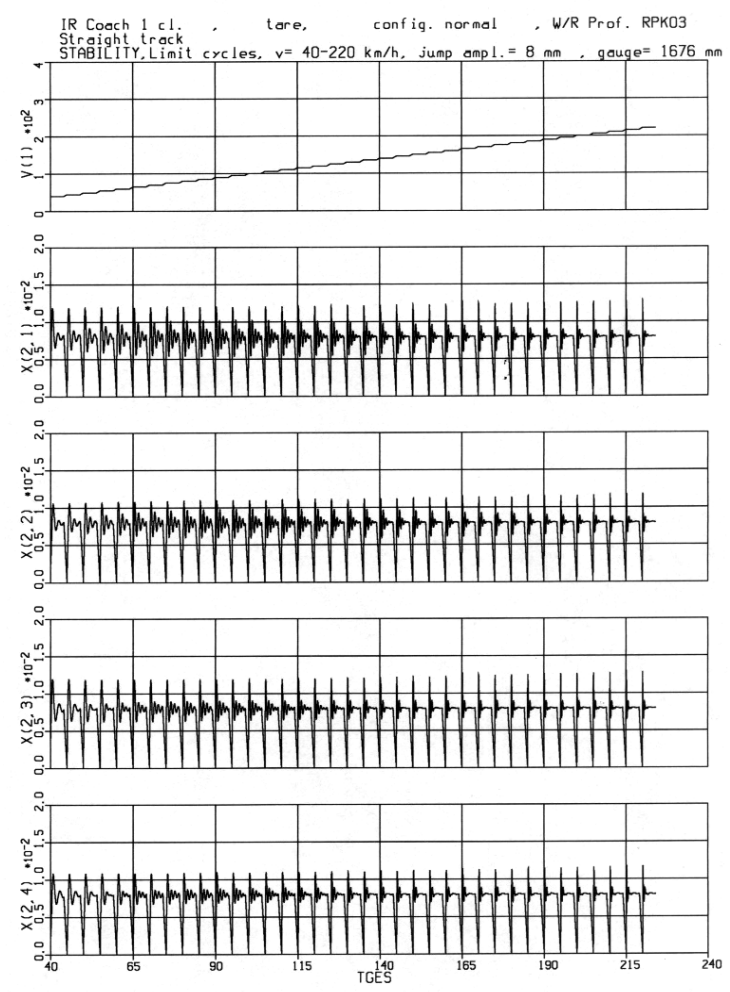

Fig. 15. Limit cycles. Graphs of lateral movements of wheelsets. Stable wagon, tested to speed of $220 \mathrm{~km} / \mathrm{h}$, in the range of medium speeds it has small damping of wheelsets especially on the first bogie (small directional stability of the body)

Rys. 15. Cykle graniczne. Wykresy przemieszczeń poprzecznych zestawów kołowych. Wagon stabilny, badany do prędkości 220 $\mathrm{km} / \mathrm{h}$, w zakresie średnich prędkości posiada małe thumienie zestawów kołowych zwłaszcza na pierwszym wózku (mała stabilność kierunkowa pudła)

\section{PODSUMOWANIE}

Przedstawione w publikacji różne metody zawansowanej analizy drgań własnych modeli matematycznych pojazdów szynowych są mało rozpowszechnione, a często nawet nie aplikowane w powszechnie stosowanych systemach symulacyjnych. Wnikliwa analiza symulacyjna zachowania pojazdów (szczególnie nietypowych) wymaga niekiedy łącznego stosowania kilku przedstawionych metod. W przypadku wykrycia nieprawidłowości konstrukcji na etapie projektu, pozwala to na ich modyfikację. Wykrycie tych nieprawidłowości później ( na etapie prototypu) wiąże się z bardziej kosztownymi badaniami tego prototypu. 
[1] Opis programu MODKAT. SIG Neuhausen, niepublikowane

[2] Sienicki A.: Prace niejawne

[3] Piechowiak T.: Prace niejawne dokonane w SIG

[4] EN 14363 Kolejnictwo. Badania własności dynamicznych dla dopuszczenia (homologacji) pojazdów szynowych. Badania własności biegowych i próby stacjonarne 